\title{
Allocation Decision: A Teaching Case for Accounting Classes
}

\author{
Sheldon R. Smith \\ Utah Valley University
}

This paper presents a teaching case for use in several possible accounting classes. The case deals with the allocation of investment income among different segments of a nonprofit entity. Students are given the opportunity to determine if a proposed allocation is appropriate or to suggest a different allocation. In either case, students are expected to justify their responses. This case allows students to do some allocation calculations and to think critically to evaluate the proposed or alternative allocations.

\section{INTRODUCTION}

In many accounting contexts, allocations are made (Zimmerman, 1995). Some of the common allocations include the following: (1) allocation of service department costs to the departments using those services (Anthony and Young, 1994; Garrison, Noreen, \& Brewer, 2015), (2) allocation of the cost of an asset over its useful life through depreciation, amortization, or depletion (Spiceland, Nelson, \& Thomas, 2020), (3) allocation of overhead costs to different activities or products in a production setting (Garrison, Noreen, \& Brewer, 2015), (4) allocation of joint costs to the multiple products produced from a common process (Garrison, Noreen, \& Brewer, 2015), (5) intraperiod tax allocation (Spiceland, Nelson, \& Thomas, 2020), and (5) allocation of revenues or expenses among different segments of an organization.

This teaching case focuses on the last of these items - the allocation of investment income among the various segments of a nonprofit association. It is loosely based on a real-life situation, but the names and numbers are disguised as they are presented in the case. It could be used in any of several classes, depending on the objective(s) to be met by the instructor. It could be used in an auditing class to discuss how an auditor should work with a client that has made allocations in the process of preparing the financial statements. It could be used in a governmental/nonprofit accounting class, as it relates to a nonprofit organization that will report net assets rather than stockholders' equity. It could be used in a managerial accounting class when different allocation methods are discussed. It could also be used in a financial accounting class as a discussion of how investment revenue should be allocated among the subentities of an organization.

Students will be given a suggested allocation of investment income from pooled investment funds across the segments of the organization. The students are then asked either to justify the allocation method used or to suggest a different allocation method. If a different allocation method is chosen, it should be justified with appropriate reasoning. This case allows students to work with specific allocation concepts and calculations, but it also allows the students to think critically about why an allocation method is appropriate or not. 


\section{CASE MATERIAL}

The Humanities Professors Association (HPA) is a nonprofit academic organization of college and university humanities professors organized to provide a forum for the exchange of ideas related to teaching and research. It started many years ago as a small group of professors from a few institutions that were geographically close to each other. However, it has grown over time. It has become a national organization, consisting of humanities professors from around the United States. It even includes some members from other countries.

The HPA is led by a Board of Directors elected by the membership of the HPA. Board members are faculty members from various institutions who serve in rotating officer positions, finally serving as the HPA president for one year and then as the past president for one year before their board membership is concluded. These officer positions are non-paid positions, and the officers get financial support from their colleges or universities for the travel and meeting attendance costs involved in their service.

To provide continuity and administrative support for these volunteer officers, a home office has been established at Eastern State University (ESU). Four employees at the home office provide ongoing marketing, administrative, technology, and bookkeeping support for the organization. One of these employees is hired as the Executive Director who is a non-voting member of the Board of Directors. The employees are treated as employees of ESU, but the HPA reimburses ESU for the compensation and benefits paid to these individuals. Because the HPA objectives are consistent with the ESU mission, ESU provides facilities and equipment to support HPA operations. The HPA pays a set annual amount to ESU as a partial reimbursement for this support. As needed, the home office contracts with lawyers and CPAs for legal and accounting expertise.

From its inception, HPA has held an annual meeting where humanities professors can come and share their teaching ideas and their research. This meeting provides a networking opportunity for college and university professors to improve the humanities curriculum and teaching methods. It also provides an outlet for professors to share and get feedback on their research. In fact, over time, HPA began publishing an academic journal six times per year as an outlet for excellent research in this academic area.

The success of the annual meetings coupled with the inability of some faculty to get funding to attend when the meetings are far away and more expensive led to the creation of regional affiliates to the national organization. These regional affiliates are part of the national organization, but they hold regional conferences annually within the geographic area of the region. To date, three regions have been created and have actively sponsored annual regional meetings: Eastern Region (EHPA), Midwest Region (MHPA) and Western Region (WHPA). These regions each have a Board of Directors, faculty elected by members and who volunteer their time to help organize the regional annual meetings. Because these regional officers are not simultaneously members of the HPA Board of Directors, they do not make decisions for the national organization, but they do make decisions for the region in which they serve.

Each region has significant autonomy in choosing the venue for its regional meeting, determining an appropriate conference registration fee, and budgeting to ensure that the meeting revenues will cover the meeting costs. The regional officers contract with a hotel in the desired location to host the meeting and provide the food and beverage for functions that are included in the meeting registration fee. This usually requires the regions to commit to a certain number of room nights that meeting attendees will utilize during the meeting. It also requires the region to commit to a certain minimum food and beverage cost that will generate additional revenue for the hotel property. By guaranteeing a specific number of room nights along with a food and beverage minimum, regions generally get a concession from the hotels that there will be no rental charges for the meeting rooms, as the hotel is already guaranteed to earn adequate revenue from the meeting through the occupied room nights and the food and beverage guarantee.

From time to time, a region may find that a specific meeting was not as successful as anticipated and meeting attendees do not fill the contracted hotel room block. This can result in a financial penalty to the region. In addition, once the contract has been signed with the hotel, if meeting attendance is lower than

expected, resulting in less than the budgeted revenue, the food and beverage minimum must still be met. Therefore, regions can have losses in some years. To plan for the risk of losses, regions often set the 
meeting registration fee above the amount that would provide an expected breakeven for the meeting. Thus, the regions typically have a positive amount of net assets on their balance sheets, as they cannot expect the national organization to step in and subsidize them. Over time, each region, as well as the national organization, has increased its net asset balance, providing a safety net for the risk of an unsuccessful meeting and to provide funds for ongoing disbursements.

Over a period of years, HPA officers have improved in budgeting for meetings and contracting with hotels. As net assets grew, the home office began investing some of the cash in investment accounts with a major national investment company to earn a return on these assets. Other funds had been kept in noninterest bearing checking accounts. Regions have also pooled some of their net assets into these investment funds, with the understanding that a larger investment pool would result in a lower expense ratio and provide for better investment opportunities. With input from the regions, the HPA Board has decided to invest approximately $60 \%$ of the invested balance in equities and the remaining $40 \%$ in bonds. Since the investment funds have typically been growing, this was determined to be an appropriate diversification to provide an appropriate return without excessive risk. The national and regional boards each determine how much to invest in the pooled funds and how much they want to keep in non-interest bearing checking accounts. Purposes for amounts in the checking accounts would be to provide for ongoing transactions, to provide a safety net of easily accessible funds, and to avoid investment risk in the pooled investment funds. For at least the last two years, no withdrawals have been made from the investment funds, and no deposits have been made except the reinvested interest and dividends earned on the existing fund balance. Per Generally Accepted Accounting Principles (GAAP), the investment fund balance is listed at fair value at each reporting date, so unrealized gains are also reflected in the fund balance.

Meeting registration fees are collected by the home office, even for the regional meetings. All expense disbursements are made by the home office, with the regional expenses first being approved by regional officers. The annual financial statements are prepared by the home office. The statements are prepared with separate columns for the national organization and each of the regions. The home office contracts with a CPA firm for the annual audit of the financial statements.

The most recent financial statements have been prepared and were recently sent out to the regional officers. Exhibit 1 shows the Statements of Financial Position for 20X5 and 20X4. Exhibit 2 shows an abbreviated Statement of Activities for 20X5. Because the HPA is a service organization mainly providing an annual meeting for attendees, general teaching and research support for academics, and a journal, the types of assets and liabilities are very limited. Office supplies are immaterial, and space and office equipment are provided by ESU. Operating revenues for the home office include mostly membership dues and meeting registration fees. Expenses are those related to meeting costs, journal publication, general support of members, and office employee costs. Since the regions have no employees, their operating revenues and expenses relate only to meeting registration fees and meeting costs. 


\section{EXHIBIT 1}

HUMANITIES PROFESSORS ASSOCIATION (HPA)

STATEMENTS OF FINANCIAL POSITION AS OF DECEMBER 31, 20X5 AND 20X4

\begin{tabular}{|c|c|c|c|c|c|}
\hline & \multicolumn{5}{|c|}{$\underline{20 \times 5}$} \\
\hline & Home & Eastern & Midwest & Western & \\
\hline & Office & Region & Region & Region & \\
\hline & $\underline{\mathrm{HPA}}$ & $\underline{E H P A}$ & MHPA & WHPA & Total \\
\hline \multicolumn{6}{|l|}{ ASSETS } \\
\hline Cash & $\$ 752,000$ & $\$ 37,000$ & $\$ 31,500$ & $\$ 27,500$ & $\$ 848,000$ \\
\hline Investments & $\$ 1,200,608$ & $\$ 228,899$ & $\$ 64,926$ & $\$ 43,567$ & $\$ 1,538,000$ \\
\hline Total Assets & $\$ 1,952,608$ & $\$ 265,899$ & $\$ 96,426$ & $\$ 71,067$ & $\$ 2,386,000$ \\
\hline \multicolumn{6}{|l|}{ LIABILITIES AND NET ASSETS } \\
\hline \multicolumn{6}{|l|}{ Liabilities } \\
\hline Accounts Payable & $\$ 27,000$ & $\$ 4,000$ & $\$ 1,500$ & $\$ 500$ & $\$ 33,000$ \\
\hline Compensation Payable & $\$ 23,000$ & & & & $\$ 23,000$ \\
\hline \multicolumn{6}{|l|}{ Net Assets } \\
\hline Unrestricted & $\$ 1,902,608$ & $\$ 261,899$ & $\$ 94,926$ & $\$ 70,567$ & $\$ 2,330,000$ \\
\hline \multirow[t]{5}{*}{ Total Liabilities and Net Assets } & $\$ 1,952,608$ & $\$ 265,899$ & $\$ 96,426$ & $\$ 71,067$ & $\$ 2,386,000$ \\
\hline & \multicolumn{5}{|c|}{$\underline{20 \times 4}$} \\
\hline & Home & Eastern & Midwest & Western & \\
\hline & Office & Region & Region & Region & \\
\hline & $\underline{\mathrm{HPA}}$ & EHPA & $\underline{\mathrm{MHPA}}$ & WHPA & Total \\
\hline \multicolumn{6}{|l|}{ ASSETS } \\
\hline Cash & $\$ 700,000$ & $\$ 30,000$ & $\$ 25,000$ & $\$ 20,000$ & $\$ 775,000$ \\
\hline Investments & $\$ 1,100,000$ & $\$ 215,000$ & $\$ 60,000$ & $\$ 40,000$ & $\$ 1,415,000$ \\
\hline Total Assets & $\$ 1,800,000$ & $\underline{\$ 245,000}$ & $\$ 85,000$ & $\$ \underline{\underline{\$ 60,000}}$ & $\underline{\underline{\$ 2,190,000}}$ \\
\hline \multicolumn{6}{|l|}{ LIABILITIES AND NET ASSETS } \\
\hline \multicolumn{6}{|l|}{ Liabilities } \\
\hline Accounts Payable & $\$ 30,000$ & $\$ 2,000$ & $\$ 1,000$ & $\$ 1,000$ & $\$ 34,000$ \\
\hline Compensation Payable & $\$ 18,000$ & & & & $\$ 18,000$ \\
\hline \multicolumn{6}{|l|}{ Net Assets } \\
\hline Unrestricted & $\$ 1,752,000$ & $\$ 243,000$ & $\$ 84,000$ & $\$ 59,000$ & $\$ 2,138,000$ \\
\hline Total Liabilities and Net Assets & $\$ 1,800,000$ & $\$ 245,000$ & $\$ 85,000$ & $\$ 60,000$ & $\$ 2,190,000$ \\
\hline
\end{tabular}




\section{EXHIBIT 2 \\ HUMANITIES PROFESSORS ASSOCIATION (HPA) STATEMENTS OF ACTIVITIES FOR THE YEAR ENDED DECEMBER 31, 20X5 (ABBREVIATED)}

\begin{tabular}{|c|c|c|c|c|c|}
\hline & \multicolumn{5}{|c|}{$20 \times 5$} \\
\hline & Home & Eastern & Midwest & Western & \\
\hline & Office & Region & Region & Region & \\
\hline & $\underline{\mathrm{HPA}}$ & $\underline{E H P A}$ & $\underline{\mathrm{MHPA}}$ & $\underline{\text { WHPA }}$ & Total \\
\hline \multicolumn{6}{|l|}{ Revenues } \\
\hline Operating Revenues & $\$ 1,100,000$ & $\$ 120,000$ & $\$ 75,000$ & $\$ 65,000$ & $\$ 1,360,000$ \\
\hline Investment Income & $\$ 100,608$ & $\$ 13,899$ & $\$ 4,926$ & $\$ 3,567$ & $\$ 123,000$ \\
\hline Less: Expenses & $(\$ 1,050,000)$ & $(\$ 115,000)$ & $(\$ 69,000)$ & $(\$ 57,000)$ & $(\$ 1,291,000)$ \\
\hline Change in Net Assets & $\$ 150,608$ & $\$ 18,899$ & $\$ 10,926$ & $\$ 11,567$ & $\$ 192,000$ \\
\hline Net assets, beginning of year & $\$ 1,752,000$ & $\$ 243,000$ & $\$ 84,000$ & $\$ 59,000$ & $\$ 2,138,000$ \\
\hline Net assets, end of year & $\$ 1,902,608$ & $\$ 261,899$ & $\$ 94,926$ & $\$ 70,567$ & $\$ 2,330,000$ \\
\hline
\end{tabular}

Amy Jackson is the newly elected treasurer of the EHPA. She looked through the statements to make sure they reflected the appropriate revenues for the regional meeting and the approved expenses for the region. She wondered about the allocation of the investment income among the different segments of the organization. After inquiring further, she was able to obtain the spreadsheet that was used to allocate the investment income. This spreadsheet is provided in Exhibit 3; Exhibit 4 shows the formulas used in this spreadsheet. Since Amy is a humanities professor, she does not have much business or accounting background. However, she is very intelligent, and she is a clear thinker. She would like your input into the allocation method used to divide the investment income. 


\section{EXHIBIT 3}

HUMANITIES PROFESSORS ASSOCIATION (HPA)

ALLOCATION OF 2OX5 INVESTMENT INCOME (INTEREST AND DIVIDENDS, WHICH WERE REINVESTED PLUS UNREALIZED INCREASE IN FAIR VALUE)

\begin{tabular}{|c|c|c|c|c|c|}
\hline & $\underline{20 \times 5}$ & & & & \\
\hline & Home & Eastern & Midwest & Western & \\
\hline & Office & Region & Region & Region & \\
\hline & $\underline{\mathrm{HPA}}$ & $\underline{E H P A}$ & MHPA & $\underline{\text { WHPA }}$ & Total \\
\hline Net assets, beginning of year & $\$ 1,752,000$ & $\$ 243,000$ & $\$ 84,000$ & $\$ 59,000$ & $\$ 2,138,000$ \\
\hline 20X5 Operating Revenues less Expenses & $\$ 50,000$ & $\$ 5,000$ & $\$ 6,000$ & $\$ 8,000$ & $\$ 69,000$ \\
\hline \multicolumn{6}{|l|}{ Net assets, end of year, before } \\
\hline investment income allocation & $\$ 1,802,000$ & $\$ 248,000$ & $\$ 90,000$ & $\$ 67,000$ & $\$ 2,207,000$ \\
\hline \multicolumn{6}{|l|}{ Average net assets for $20 \times 5$, before } \\
\hline \multicolumn{6}{|l|}{ investment income allocation } \\
\hline ((beg. bal. + end. bal.)/2) & $\$ 1,777,000$ & $\$ 245,500$ & $\$ 87,000$ & $\$ 63,000$ & $\$ 2,172,500$ \\
\hline \multicolumn{6}{|l|}{ Percentage of investment income } \\
\hline \multicolumn{6}{|l|}{ (Average net assets (per column)/ } \\
\hline Total average net assets) & $81.80 \%$ & $11.30 \%$ & $4.00 \%$ & $2.90 \%$ & $100.00 \%$ \\
\hline Investment Income & $\$ 100,608$ & $\$ 13,899$ & $\$ 4,926$ & $\$ 3,567$ & $\$ 123,000$ \\
\hline \multicolumn{6}{|l|}{ Investment balance, beginning of year } \\
\hline at fair value & $\$ 1,415,000$ & & & & \\
\hline \multicolumn{6}{|l|}{ Investment balance, end of year } \\
\hline \multicolumn{6}{|l|}{ at fair value (including reinvested } \\
\hline \multicolumn{6}{|l|}{ interest and dividends--no additional) } \\
\hline \multicolumn{6}{|l|}{ investments or withdrawals were } \\
\hline made during the year) & $\$ 1,538,000$ & & & & \\
\hline Investment Income & $\$ 123,000$ & & & & \\
\hline
\end{tabular}




\section{EXHIBIT 4 \\ HUMANITIES PROFESSORS ASSOCIATION (HPA) \\ ALLOCATION OF 20X5 INVESTMENT INCOME (INTEREST AND DIVIDENDS, WHICH WERE REINVESTED PLUS UNREALIZED INCREASE IN FAIR VALUE)}

\begin{tabular}{|c|c|c|c|c|c|c|}
\hline 8 & & $\underline{20 \times 5}$ & & & & \\
\hline 9 & & Home & Eastern & Midwest & Western & \\
\hline 10 & & Office & Region & Region & Region & \\
\hline 11 & & $\underline{\mathrm{HPA}}$ & $\underline{\text { EHPA }}$ & MHPA & WHPA & $\underline{\text { Total }}$ \\
\hline 12 & Net assets, beginning of year & 1752000 & 243000 & 84000 & 59000 & $=\mathrm{E} 12+\mathrm{D} 12+\mathrm{C} 12+\mathrm{B} 12$ \\
\hline \multicolumn{7}{|l|}{13} \\
\hline 14 & $20 \times 5$ Operating Revenues less Expenses & 50000 & 5000 & 6000 & 8000 & $=\mathrm{E} 14+\mathrm{D} 14+\mathrm{C} 14+\mathrm{B} 14$ \\
\hline \multicolumn{7}{|l|}{15} \\
\hline 16 & Net assets, end of year, before & & & & & \\
\hline 17 & investment income allocation & $=\mathrm{B} 12+\mathrm{B} 14$ & $=\mathrm{C} 12+\mathrm{C} 14$ & $=\mathrm{D} 12+\mathrm{D} 14$ & $=\mathrm{E} 12+\mathrm{E} 14$ & $=\mathrm{E} 17+\mathrm{D} 17+\mathrm{C} 17+\mathrm{B} 17$ \\
\hline \multicolumn{7}{|l|}{18} \\
\hline 19 & Average net assets for $20 \times 5$, before & & & & & \\
\hline 20 & investment income allocation & & & & & \\
\hline 21 & ((beg. bal. + end. bal.)/2) & $=(\mathrm{B} 17+\mathrm{B} 12) / 2$ & $=(\mathrm{C} 17+\mathrm{C} 12) / 2$ & $=(\mathrm{D} 17+\mathrm{D} 12) / 2$ & $=(\mathrm{E} 17+\mathrm{E} 12) / 2$ & $=\mathrm{E} 21+\mathrm{D} 21+\mathrm{C} 21+\mathrm{B} 21$ \\
\hline \multicolumn{7}{|l|}{22} \\
\hline 23 & Percentage of investment income & & & & & \\
\hline 24 & (Average net assets (per column)/ & & & & & \\
\hline 25 & Total average net assets) & $=B 21 / \$ F \$ 21$ & $=C 21 / \$ F \$ 21$ & $=\mathrm{D} 21 / \mathbf{S F} \$ 21$ & $=E 21 / \$ F \$ 21$ & $=\mathrm{E} 25+\mathrm{D} 25+\mathrm{C} 25+\mathrm{B} 25$ \\
\hline \multicolumn{7}{|l|}{26} \\
\hline 27 & Investment Income & $=\mathrm{B} 25^{*} \$ \mathrm{~B} \$ 36$ & $=\mathrm{C} 25^{*} \$ \mathrm{~B} \$ 36$ & $=\mathrm{D} 25^{*} \$ \mathrm{~B} \$ 36$ & $=\mathrm{E} 25^{*} \$ \mathrm{~B} \$ 36$ & $=\mathrm{E} 27+\mathrm{D} 27+\mathrm{C} 27+\mathrm{B} 27$ \\
\hline \multicolumn{7}{|l|}{28} \\
\hline 29 & Investment balance, beginning of year & & & & & \\
\hline 30 & at fair value & 1415000 & & & & \\
\hline 31 & Investment balance, end of year & & & & & \\
\hline 32 & at fair value (including reinvested & & & & & \\
\hline 33 & interest and dividends--no additional) & & & & & \\
\hline 34 & investments or withdrawals were & & & & & \\
\hline 35 & made during the year) & $\underline{1538000}$ & & & & \\
\hline 36 & Investment Income & $=\mathrm{B} 35-\mathrm{B} 30$ & & & & \\
\hline 37 & & & & & & \\
\hline
\end{tabular}

\section{CASE REQUIREMENTS FOR STUDENTS}

Look at the allocation of investment income among the different segments of the HPA. Analyze how the allocation was made and determine whether you feel the allocation is appropriate or not. If you feel it is appropriate, provide reasons to justify why you feel this way. If you feel there is a better way to allocate this income, provide calculations showing your preferred method and provide reasons to justify your preference. Present your justifications in a way that you think will make sense to Amy Jackson.

\section{TEACHERS' NOTE}

This case is not very long. The students could be given the case in advance and asked to read it. Either on their own or in groups, they could consider the appropriateness of the proposed allocation of investment income or present an alternative. The case discussion in class should easily fit within one class period. It is important to allow the students to think critically about the allocation process and make their arguments supporting either the proposed allocation method or their alternative. The allocation of expenses or revenues can have different objectives, so it will be informative to allow students to express their thoughts before leading them in a specific direction.

Hopefully, students will bring up the allocation base used in the proposed allocation - the average net assets of each segment - and determine that this might not be the best allocation for this situation. Since each segment can choose how much to put at risk compared to how much it holds in non-interest bearing 
checking accounts, it would seem to make more sense in this case to allocate the investment income over the average investment account balance for each segment. Since no additional investments or withdrawals were made during the year, an easy allocation could simply divide the investment increase proportionately over the beginning investment account balances for each segment. Using this simple allocation, the investment income would be allocated as follows:

$\begin{array}{ll}\text { Home Office } & (\$ 1,100,000 / \$ 1,415,000) \times \$ 123,000=\$ 95,618 \\ \text { Eastern Region } & (\$ 215,000 / \$ 1,415,000) \times \$ 123,000=\$ 18,689 \\ \text { Midwest Region } & (\$ 60,000 / \$ 1,415,000) \times \$ 123,000=\$ 5,216 \\ \text { Western Region } & (\$ 40,000 / \$ 1,415,000) \times \$ 123,000=\$ 3,477\end{array}$

If a comparison is made between these two different allocation methods, it becomes obvious that the proposed allocation gives the Home Office and WHPA more and EHPA and MHPA less than the allocation based on investment account amounts.

\begin{tabular}{|c|c|c|c|c|}
\hline & $\begin{array}{l}\text { Proposed } \\
\text { Allocation }\end{array}$ & $\begin{array}{l}\text { Improved } \\
\text { Allocation }\end{array}$ & $\underline{\text { Difference }}$ & $\begin{array}{l}\text { Difference as Percent } \\
\text { of Proposed Allocation }\end{array}$ \\
\hline Home Office & $\$ 100,608$ & $\$ 95,618$ & $\$ 4,990$ & $5.0 \%$ \\
\hline Eastern Region & $\$ 13,899$ & $\$ 18,689$ & $(\$ 4,790)$ & $(34.5 \%)$ \\
\hline Midwest Region & $\$ 4,926$ & $\$ 5,216$ & $(\$ 290)$ & $(5.9 \%)$ \\
\hline Western Region & $\$ \quad 3,567$ & $\$ \quad 3,477$ & $\$ 90$ & $2.5 \%$ \\
\hline Total & $\overline{\$ 123,000}$ & $\overline{\$ 123,000}$ & & \\
\hline
\end{tabular}

This is because the Home Office and WHPA have a much higher percentage of their net assets in non-interest bearing checking accounts compared to EHPA and MHPA, which have a much higher percentage of their net assets in the pooled investment funds. If the percent difference is also examined, it becomes obvious why Amy Jackson may have initially been wondering about the allocation proposed. While the differences may not seem material, percentage-wise, for the home office and the other regions, the percentage difference for EHPA is quite large.

An analogy to this situation could be raised. What if an employer has a defined contribution pension plan and contributes a specific amount each month for each employee. The employees can choose how the contributions for them will be invested among the different fund options - more in risky funds or more in less risky funds - depending on their risk tolerance. However, at the end of each period, the investment company takes the total returns and divides them equally across all funds regardless of individual fund risk or return. How would you feel if you were willing to bear more risk but got the same rate of return as those who were unwilling to bear risk? How would you feel if you chose less risky funds but ended up with an investment loss because the riskier funds you avoided lost value?

In fact, in the proposed allocation, think about what could happen if there are losses in the investment account. If the board members of one region anticipated the losses and withdrew that region's money from the investment funds and put it into their checking account to avoid the market risk, that region could still be allocated a loss if the loss is allocated across average net assets rather than on the average amount invested. Although that region wanted to avoid risk, it was unable to do so, because the allocation method was not consistent with the risk choices made by that region. In a risk-return tradeoff situation, the returns should be allocated where the risk lies, not in some other fashion.

The proposed allocation may also produce counterintuitive results or gamesmanship that may actually be detrimental to the organization. If segment leaders become aware of this allocation based on average net assets, they may intentionally keep more funds in the non-interest bearing checking accounts, thinking they will share in the investment gains anyway. However, as more and more funds are shifted to checking accounts, the investment account balance will become smaller, reducing possible investment income available to allocate. 
In the case given, no investments or withdrawals were made to or from the investment funds. If investments or withdrawals occurred during the year, it would be better to use some average investment balance, either a simple average or a weighted average, depending on the amounts and timing of the deposits and withdrawals (and perhaps on the timing of the investment account increases, both realized and unrealized).

It may also be interesting to discuss why the auditors would have approved the allocation in the proposed method. Are there any reasons why or situations in which the proposed allocation might be appropriate?

\section{CLASSROOM VALIDATION AND FEEDBACK}

This case was tested in a senior-level governmental/nonprofit accounting class during the Summer Semester of 2018. The case was distributed about one week before the class discussion of the case. Some of the students had read the case and thought about the concepts presented prior to the discussion in class, especially because they had a class assignment to provide a written response to the case requirements. The class participation was adequate, with a few of the class members openly participating in the case discussion. Other students may not have been as prepared as they could have been because of other class assignments for the governmental/nonprofit class and exams and assignments in other classes, especially due to the nature of the double-speed summer term.

Approximately 30 minutes was devoted to the class discussion. One class member first suggested that the allocation be made based on the investment balance rather than the average net asset balance, but he had used the end of the year investment balances (after the proposed allocation) for his suggested allocation. Another student indicated that the allocation base should be the investment balances but that the beginning-of-year balances should be used for the allocation. Other students agreed that the allocation of investment income should be based on the investment balances at the beginning of the year rather than the average net asset balances.

After the case discussion, students were asked for anonymous feedback about their perspectives on the case and the case discussion experience through a survey instrument. The survey included several items rated on a Likert-type scale and two open-ended items for comments. The Likert-type items were rated by the students from strongly agree (5) to strongly disagree (1). Average ratings for these items are provided in Table 1.

TABLE 1

STUDENT FEEDBACK ON CASE-STRONGLY AGREE (5) TO STRONGLY DISAGREE (1)

\begin{tabular}{|l|c|c|}
\hline \multicolumn{1}{|c|}{ Item } & $\mathrm{n}$ & Mean \\
\hline This case helped me to learn new information. & 19 & 4.37 \\
\hline This case caused me to think critically about the issues presented. & 19 & 4.42 \\
\hline The case presented a topic that was worthwhile to discuss. & 19 & 4.37 \\
\hline The case content was interesting to me. & 19 & 3.95 \\
\hline The instructions and background information in the case were clear. & 19 & 4.16 \\
\hline This case was a positive learning experience. & 19 & 4.42 \\
\hline The case requirements were appropriate for the material presented in the case. & 19 & 4.32 \\
\hline Class discussion of this case improved my understanding of the case content. & 19 & 4.58 \\
\hline Class discussion of this case caused additional critical thinking. & 19 & 4.47 \\
\hline
\end{tabular}

Most of the means are between 4 and 5, indicating a general level of agreement with those statements. The highest means on the last two items indicate that the actual class discussion was very helpful to the students in assisting them to understand the case material and think critically about it. One statement about the level of student interest in the case content had a mean slightly below 4.00, still above the 
neutral point, but indicating the possibility that this case may not have fit well within the course content coverage, at least not at the point in the class when the case was discussed.

\section{CONCLUSION}

This case was successfully used in a classroom setting, and the objectives of the case were met. Student feedback was generally positive. Although it will likely be obvious to the students that the numbers in this case are disguised, they may find the case more interesting knowing that it is based on a real-life situation for a nonprofit entity. This case gives students an opportunity to evaluate a proposed method for allocating investment income among segments of a nonprofit entity. They can think about an

appropriate allocation base and use critical thinking skills to provide justification for either the proposed allocation method or an alternative method.

\section{REFERENCES}

Anthony, R.N., \& Young, D.W. (1994). Management Control in Nonprofit Organizations ( $5^{\text {th }}$ ed.). Burr Ridge, IL: Irwin.

Garrison, R.H., Noreen, E.W., \& Brewer, P.C. (2015). Managerial Accounting (15 ${ }^{\text {th }}$ ed.). New York, NY: McGraw-Hill Education.

Spiceland, J.D., Nelson, M.W., \& Thomas, W.B. (2020). Intermediate Accounting (10 ${ }^{\text {th }}$ ed.). New York, NY: McGraw-Hill Education.

Zimmerman, J.D. (1995). Accounting for Decision Making and Control. Chicago, IL: Richard D. Irwin, Inc. 